\title{
Nitrogen-nitrogen bond cleavage catalyzed by ruthenium complexes
}

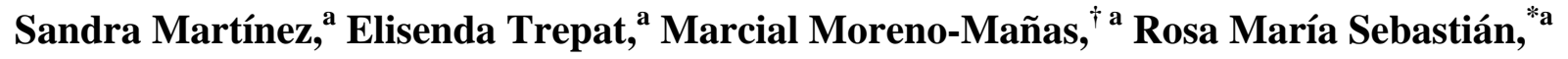 \\ Adelina Vallribera, ${ }^{* a}$ Ignasi Mata $^{\mathrm{b}}$, and Elies Molins ${ }^{\mathrm{b}}$ \\ ${ }^{a}$ Department of Chemistry, Universitat Autònoma de Barcelona, 08193-Cerdanyola del Vallès, \\ Barcelona, Spain \\ ${ }^{b}$ Institut de Ciència de Materials de Barcelona (CSIC), Campus de la UAB, 08193-Cerdanyola \\ del Vallès, Barcelona, Spain \\ E-mail: adelina.vallribera@uab.es
}

Dedicated to Prof. Joan Bosch on the occasion of his $60^{\text {th }}$ birthday

\begin{abstract}
Several ruthenium complexes have been tested as catalysts for the cleavage of nitrogen-nitrogen bonds of mono, di and trisubstituted hydrazine derivatives. Better results were obtained using $\mathrm{Ru}_{3}(\mathrm{CO})_{12}$ as catalyst in this type of reactions. Addition of hydrogen sources, such as isopropanol or sodium hydride, to the reaction mixtures has been studied in order to improve the cleavage process.
\end{abstract}

Keywords: Nitrogen-nitrogen bond cleavage, ruthenium catalyst, hydrazine, azodicarboxylate

\section{Introduction}

Reductive cleavage of the nitrogen-nitrogen bond of hydrazines is a key step in a number of asymmetric syntheses of amines and amino acids. There are few general methods available for this reaction, and in most cases the conditions required to cleave this bond can depend markedly on the substituents attached to it. In general, non-aromatic hydrazines are much more difficult to reduce than aromatic hydrazines, and partially substituted hydrazines are more resistant to reduction than fully substituted ones. ${ }^{1}$ The most widely used method for the cleavage of alkylhydrazines is catalytic hydrogenolysis over Raney nickel, platinum or (less commonly) palladium. $^{2}$ However these reactions often require the use of hydrogen under pressure and frequently the addition of acids. Hydrogenations using internal generated hydrogen have also been described. ${ }^{3}$ Moreover, hydrazides can be cleaved electroreductively or by electron transfer from metals, sodium in liquid ammonia being the most widely used reagent; this method is

${ }^{\dagger}$ Deceased on $20^{\text {th }}$ February 2006 
mainly used with cyclic hydrazides where reaction is facilitated by relief of ring strain. ${ }^{4}$ Diborane has occasionally been used, however it also reduces the carbonyl groups. ${ }^{5} \mathrm{SmI}_{2}$ has been described as a good reducing agent for the cleavage of nitrogen-nitrogen bond of arylhydrazines $^{6}$ and several polynuclear complexes of tungsten and ruthenium have shown the ability to cleave these type of bonds, but only when using $\mathrm{RuMo}_{3} \mathrm{~S}_{4}$ clusters $^{7 \mathrm{e}}$ the process being catalytic. However, no general synthetic methodology has been published until now, to the best of our knowledge. ${ }^{7}$

Therefore, although several methods to cleave nitrogen-nitrogen bonds are described in the literature, a small number of them do not use molecular hydrogen. Unexpected results obtained in our group started the work presented in this paper. It was known in the literature that conjugate additions of $\beta$-dicarbonyl compounds to several unsaturated derivatives could be performed through catalysis of ruthenium(II) species. When the reaction of 2-ethyl-1,3-diphenyl1,3-propanedione $\mathbf{1}$ with diethyl azodicarboxylate $\mathbf{2}$ in the presence of tris(triphenylphosphane)ruthenium(II) chloride $^{8}$ was carried out, the corresponding dialkylated $\beta$-dicarbonyl compound 3 was obtained in good yield (83\%) (Scheme 1). However, when the same reaction was catalyzed by tetrakis(triphenylphosphane)ruthenium(II) hydride, ${ }^{9}$ unexpected compounds were isolated. ${ }^{10}$ The formation of $\mathbf{4}$ and 5 must involve the cleavage of the N-N bond. Initially, phosphane was proposed to be responsible for the N-N activation. However, phosphane has also been used by some of us as catalyst of these conjugate additions reactions, and only a small amount of compounds $\mathbf{4}$ and $\mathbf{5}$ were detected. ${ }^{11}$ These results prompted us to test the tetrakis(triphenylphosphane)ruthenium(II) hydride and other commercial ruthenium based complexes as catalysts for the cleavage of $\mathrm{N}-\mathrm{N}$ bonds of simple hydrazines and azodicarboxylate derivates In fact, several non-hydrogenolitic methods described in the literature did not work with compounds of type 3 , or similar monoalkylated species. ${ }^{4,6}$

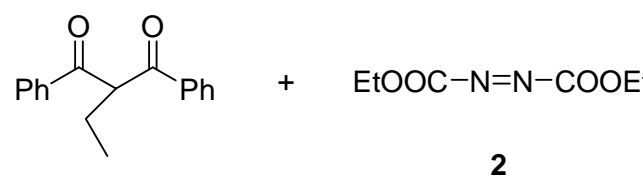

1

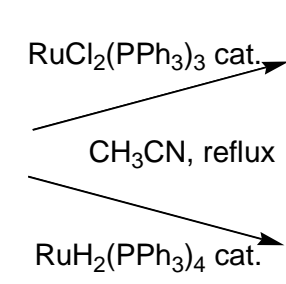

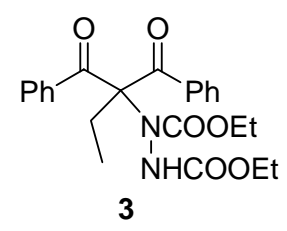

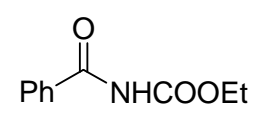

4

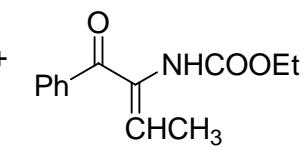

5

Scheme 1. Conjugate additions of $\beta$-dicarbonyl compound to diethyl azodicarboxylate catalyzed by ruthenium(II) species. ${ }^{10}$ 


\section{Results and Discussion}

Six commercially available mono and disubstituted hydrazines have been chosen in order to test different ruthenium catalyst's activity in the cleavage process of nitrogen-nitrogen bonds (Scheme 2 and Table 1). Three different ruthenium complexes were selected, the previously mentioned $\mathrm{RuH}_{2}\left(\mathrm{PPh}_{3}\right)_{4}$, $\left.[\mathrm{Ru}(\mathrm{AcO}) \mathrm{CO})_{2}\right]_{\mathrm{x}}$ and $\mathrm{Ru}_{3}(\mathrm{CO})_{12}$, containing metal atoms in three different oxidation states, 2, 1 and 0 respectively. We thought that low valence ruthenium complexes should be also a good option because of their low redox potential and higher affinity towards heteroatom compounds. ${ }^{12}$

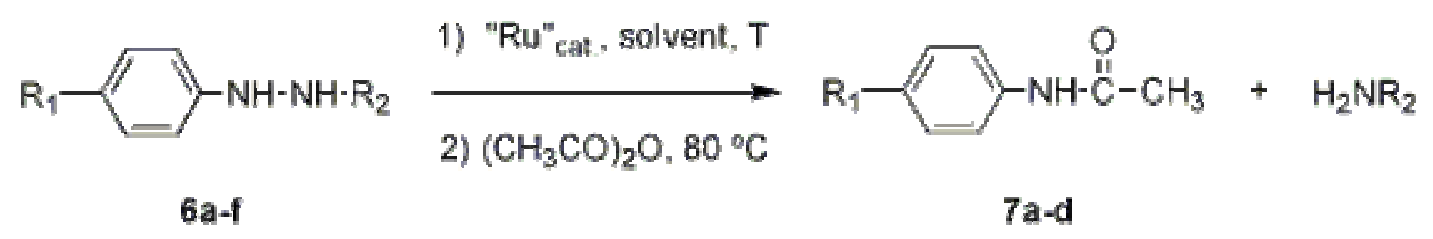
a) $R_{1}=-H, R_{2}=-C_{6} H_{5}$
b) $R_{1}=-H_{1}, R_{2}=-H$
c) $R_{1}=-O M e, R_{2}=-H$
d) $R_{1}=-M e_{1} R_{2}=-H$
e) $\mathrm{R}_{1} \equiv-\mathrm{NO}_{2}, \mathrm{R}_{2} \equiv-\mathrm{H}$
f) $\mathrm{R}_{1}=-\mathrm{H}_{2}, \mathrm{R}_{2}=-\mathrm{COCH}_{3}$

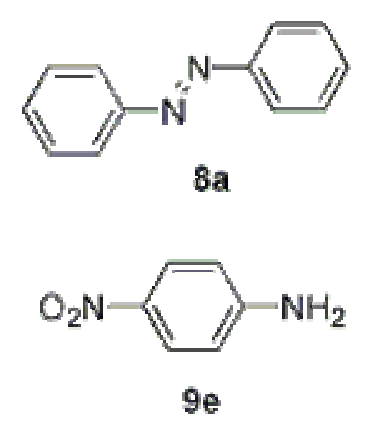

Scheme 2. Cleavage of N-N bonds of aryl hydrazines catalyzed by ruthenium. See experimental conditions in Table 1.

First studies were carried out with 1,2-diphenylhydrazine 6a in the presence of the three catalysts. Cleavage of the nitrogen-nitrogen bond was observed in moderate yields when 6a was treated with $6 \%$ molar of $\mathrm{Ru}_{3}(\mathrm{CO})_{12}$ or $\left.[\mathrm{Ru}(\mathrm{AcO}) \mathrm{CO})_{2}\right]_{\mathrm{x}}$ in refluxing acetonitrile under inert atmosphere (Entries 1 and 2 respectively). In both cases azobenzene 8a, coming from an oxidizing process, was also isolated. Curiously enough, $\mathrm{RuH}_{2}\left(\mathrm{PPh}_{3}\right)_{4}$ was not a good catalyst for this transformation, and starting material was recovered after 24 hours (Entry 3). This result was initially quite surprising for us, taking into account our previously mentioned results (Scheme $1)^{10}$. However quite recent results in the literature indicate that hydrogenolysis of $\mathbf{6 a}$ can be only achieved using $\mathrm{RuH}_{2}\left(\mathrm{PPh}_{3}\right)_{4}$ under high hydrogen pressures. ${ }^{13}$ On the other hand pretty good results have been obtained in this work with commercially available $\mathrm{Ru}_{3}(\mathrm{CO})_{12}$. A blank experiment (without catalyst) was also made with 6a, recovering only starting material contamined by 8a. In order to achieve easier purification processes of the prepared anilines, reaction mixtures were treated in all cases with acetic anhydride in order to isolate the 
corresponding $N$-acetylated anilines (Scheme 2).

Both active catalysts were also tested over phenylhydrazine, $\mathbf{6 b}$, in the same reaction conditions (Entries 8 and 9); in this case better results were obtained using $\mathrm{Ru}_{3}(\mathrm{CO})_{12}$ as catalyst, being $N$-phenylacetamide isolated in 51\% yield. Three $p$-substituted phenyl hydrazines $\mathbf{6 c - e}$ were also chosen as substrates. p-Methoxyphenylhydrazine 6c and 1-p-tolylhydrazine $\mathbf{6 d}$ gave the corresponding $N$-acetylated anilines in moderate yields using also $\mathrm{Ru}_{3}(\mathrm{CO})_{12}$ as catalyst (Entries 11 and 13). The other product from these N-N bond scission reactions is volatile ammonia. However, under the same experimental conditions, 6e containing and electron withdrawing group $\left(-\mathrm{NO}_{2}\right)$ in the para position of the aromatic ring, gave complex reaction mixtures, the corresponding $N$-acetylated aniline being isolated in poor yield (Entry 15). Moreover, the stability of $\mathbf{6 e}$ was tested in the selected experimental conditions without the catalyst and pure starting material being recovered. Poor results were obtained when the reduction of $\mathbf{6 e}$ was carried out with $\left.[\mathrm{Ru}(\mathrm{AcO}) \mathrm{CO})_{2}\right]_{\mathrm{x}}$ (Entry 16). $\mathrm{N}$-acetylphenylhydrazine $6 \mathbf{f}$ did not react (Entry 17).

After these preliminary results we decided to continue our tests with the most active and versatile catalyst, $\mathrm{Ru}_{3}(\mathrm{CO})_{12}$ in order to extend the method. The studied cleavage of nitrogennitrogen bond involves a redox process, where nitrogen atoms of hydrazine groups are reduced to amino groups. In order to improve the previously presented results, we considered the possibility to use different hydrogen sources as for example isopropanol. As in the MeerweinPonndorf-Verley reduction, isopropanol can act as hydrogen donor in the presence of ruthenium, a redox process such as that represented in Scheme 3 being envisaged. The process involves metal hydride intermediates instead of a direct transfer of hydride. ${ }^{12,14}$ A similar strategy has been used for the direct cleavage and conversion of N-N bonds to $\mathrm{N}$-(tert-butyloxy)carbamates, reactions being carried out in the presence of a safe hydride source, polymethylhydrosiloxane, and catalytic amounts of Pd-C. ${ }^{15}$ In general, details of this mechanism are not clear and depend on the ruthenium complex, ligands and the hydrogen donor.

Futhermore, better results for the cleavage of nitrogen-nitrogen bonds were obtained when hydrazines 6a-d were treated with $\mathrm{Ru}_{3}(\mathrm{CO})_{12}$ in a isopropanol:acetonitrile (1:2) mixture (Entry 4) or using pure isopropyl alcohol as solvent (Entries 5, 10, 12, 14). Once more, oxidation compound 8a was isolated when the reaction was performed with 6a. Reaction times increased when isopropanol was used as solvent with 6b-d. $N, N$-diacetylated amines were also isolated with $\mathbf{6 b}$ and $\mathbf{6 d}$ as the starting materials (Entries 10 and 14). This diacetylation could be avoided performing the protecting reaction at room temperature (Entry 12). 
Table 1. Results of the cleavage of $\mathrm{N}-\mathrm{N}$ bonds promoted by ruthenium complexes (Scheme 2 and Scheme 4)

\begin{tabular}{|c|c|c|c|c|c|}
\hline Entry & Substrate & Catalyst (6\% M) & $\begin{array}{c}\text { Experimental } \\
\text { conditions }\end{array}$ & $\begin{array}{l}\text { Reaction } \\
\text { time (h) }\end{array}$ & Products (yield \%) \\
\hline 1 & $6 \mathbf{a}$ & $\mathrm{Ru}_{3}(\mathrm{CO})_{12}$ & {$[\mathrm{a}]$} & 24 & $7 \mathbf{a}(35)[\mathrm{h}]+\mathbf{8 a}(50)$ \\
\hline 2 & $6 a$ & {$\left[\mathrm{Ru}(\mathrm{AcO})(\mathrm{CO})_{2}\right]_{\mathrm{x}}$} & [a] & 24 & $7 \mathbf{a}(34)[\mathrm{h}]+\mathbf{8 a}(40)$ \\
\hline 3 & $6 a$ & $\mathrm{RuH}_{2}\left(\mathrm{PPh}_{3}\right)_{4}$ & [a] & 24 & No reaction [i] \\
\hline 4 & $6 a$ & $\mathrm{Ru}_{3}(\mathrm{CO})_{12}$ & [b] & 24 & $7 \mathbf{a}(40)[h]+8 \mathbf{a}(33)$ \\
\hline 5 & $6 a$ & $\mathrm{Ru}_{3}(\mathrm{CO})_{12}$ & [c] & 24 & $7 \mathbf{a}(48)[\mathrm{h}]+\mathbf{8 a}(30)$ \\
\hline 6 & $6 a$ & $\mathrm{Ru}_{3}(\mathrm{CO})_{12}$ & [d] & 18 & $7 \mathbf{a}(31)[\mathrm{h}]+\mathbf{8 a}(19)$ \\
\hline 7 & $6 a$ & $\mathrm{Ru}_{3}(\mathrm{CO})_{12}$ & [e] & 24 & $7 \mathbf{a}(26)[\mathrm{h}]+\mathbf{8 a}(10)$ \\
\hline 8 & $6 \mathrm{~b}$ & $\mathrm{Ru}_{3}(\mathrm{CO})_{12}$ & [a] & 24 & $\mathbf{7 b}(51)$ \\
\hline 9 & $6 \mathbf{b}$ & {$\left[\mathrm{Ru}(\mathrm{AcO})(\mathrm{CO})_{2}\right]_{\mathrm{x}}$} & [a] & 24 & $7 \mathbf{b}(20)$ \\
\hline 10 & $6 b$ & $\mathrm{Ru}_{3}(\mathrm{CO})_{12}$ & [c] & 44 & $7 \mathbf{b}(12)[j]$ \\
\hline 11 & $6 c$ & $\mathrm{Ru}_{3}(\mathrm{CO})_{12}$ & [a] & 24 & 7c (30) \\
\hline 12 & $6 c$ & $\mathrm{Ru}_{3}(\mathrm{CO})_{12}$ & [c] & 48 & $7 c(50)$ \\
\hline 13 & 6d & $\mathrm{Ru}_{3}(\mathrm{CO})_{12}$ & [a] & 24 & 7d (33) \\
\hline 14 & 6d & $\mathrm{Ru}_{3}(\mathrm{CO})_{12}$ & [c] & 42 & 7d (33) [k] \\
\hline 15 & $6 e$ & $\mathrm{Ru}_{3}(\mathrm{CO})_{12}$ & [a] & 24 & $\mathbf{9 e}(17)$ \\
\hline 16 & $6 e$ & {$\left[\mathrm{Ru}(\mathrm{AcO})(\mathrm{CO})_{2}\right]_{\mathrm{x}}$} & [a] & 24 & Complex mixture \\
\hline 17 & $6 f$ & $\mathrm{Ru}_{3}(\mathrm{CO})_{12}$ & [a] & 24 & No reaction [i] \\
\hline 18 & $10 a$ & $\mathrm{Ru}_{3}(\mathrm{CO})_{12}$ & [f] & 72 & 11a (31) \\
\hline 19 & $10 a$ & $\mathrm{RuH}_{2}\left(\mathrm{PPh}_{3}\right)_{4}$ & {$[\mathrm{f}]$} & 72 & 11a (10) \\
\hline 20 & $10 a$ & $\mathrm{Ru}_{3}(\mathrm{CO})_{12}$ & [b] & 240 & $11 a(10)$ \\
\hline 21 & $10 a$ & $\mathrm{Ru}_{3}(\mathrm{CO})_{12}$ & [g] & 72 & $11 a(24)$ \\
\hline 22 & $10 b$ & $\mathrm{Ru}_{3}(\mathrm{CO})_{12}$ & {$[\mathrm{f}]$} & 72 & $11 b(37)$ \\
\hline 23 & $10 b$ & $\mathrm{Ru}_{3}(\mathrm{CO})_{12}$ & [g] & 72 & $11 b(10)$ \\
\hline 24 & 3 & $\mathrm{Ru}_{3}(\mathrm{CO})_{12}$ & [f] & 72 & No reaction [i] \\
\hline 25 & 12 & $\mathrm{Ru}_{3}(\mathrm{CO})_{12}$ & {$[\mathrm{f}]$} & 72 & No reaction [i] \\
\hline
\end{tabular}

[a] $\mathrm{CH}_{3} \mathrm{CN}$ at reflux. [b] $i-\mathrm{PrOH}: \mathrm{CH}_{3} \mathrm{CN}(1: 2)$ at reflux. [c] $i-\mathrm{PrOH}$ at reflux. [d] $\mathrm{NaH}, i-$ $\mathrm{PrOH}: \mathrm{CH}_{3} \mathrm{CN}$ (1:2) at reflux. [e] $\mathrm{HCOOH} / \mathrm{Et}_{3} \mathrm{~N}, \mathrm{CH}_{3} \mathrm{CN}$ at reflux. [f] $\mathrm{CH}_{3} \mathrm{CN}$ at $120{ }^{\circ} \mathrm{C}$ in a closed reactor. [g] $i$ - $\mathrm{PrOH}: \mathrm{CH}_{3} \mathrm{CN}(1: 2)$ at $120^{\circ} \mathrm{C}$ in a closed reactor. [h] Yield calculated considering the stoichiometry of the reaction 6a:7a (1:2). [i] Starting material recovered. [j] Diacetylated aniline was also isolated in $28 \%$ yield. [k] Diacetylated p-toluidine was also isolated in $28 \%$ yield. 


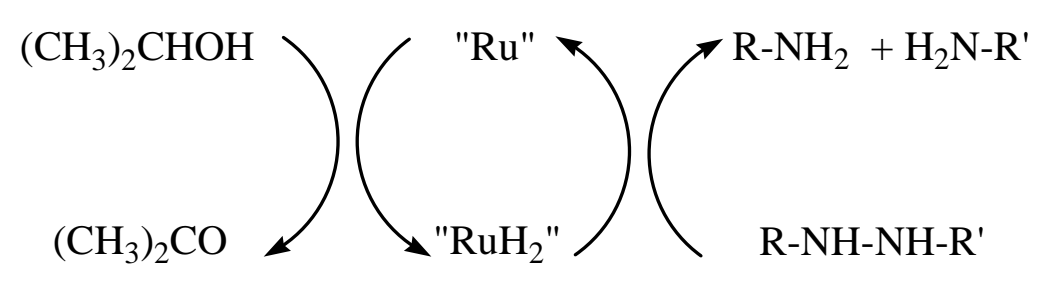

Scheme 3. Redox process of cleavage nitrogen-nitrogen bond in the presence of isopropanol catalyzed by ruthenium. ${ }^{12}$

Addition of sodium hydride to the mixtures of isopropanol/acetonitrile in the presence of 6a did not improve the yield of the cleavage products (compare Entry 6 with Entries 4 and 5).

Formic acid in basic media in the presence of ruthenium species can also act as a hydride donor. ${ }^{12,16}$ However, when $\mathbf{6 a}$ was treated with formic acid and triethylamine in the presence of catalytic amounts of $\mathrm{Ru}_{3}(\mathrm{CO})_{12}$ in refluxing acetonitrile, $N$-phenylacetamide was obtained in a modest 26\% yield (Entry 7), similar result to that obtained in the reaction performed in acetonitrile without the presence of any hydrogen donor. It is interesting to note that the formation of compound 8a was remarkably reduced. Similar behavior was observed in the experiment performed with sodium hydride (Entry 6). In both cases these results were expected because the reactions were carried out in reducing media.

As a conclusion, we recommend the use of $\mathrm{Ru}_{3}(\mathrm{CO})_{12}$ as catalyst in the presence of isopropyl alcohol as solvent for the cleavage of nitrogen-nitrogen bond of aryl hydrazines.

As mentioned in the introduction, our research group was interested in azodicarboxylate derivatives of $\beta$-dicarbonyl compounds. ${ }^{17}$ These compounds can be easily achieved by Michael addition reactions. ${ }^{10,18}$ The cleavage of nitrogen-nitrogen bonds of the alkylhydrazino groups would be a good method to introduce amino functions in the intercarbonylic position (electrophilic amination). ${ }^{19}$ If starting materials are $\beta$-ketoesters, this cleavage process would allow to achieve $\alpha$-aminoacid derivatives. For that purpose we prepared compounds $10 \mathbf{a}, \mathbf{b}^{20}$ (Scheme 4) and they were treated with a catalytic amount of $\mathrm{Ru}_{3}(\mathrm{CO})_{12}$ in refluxing acetonitrile. Under these conditions no reaction was observed, however, under more drastic conditions, heating at $120^{\circ} \mathrm{C}$ in a closed reactor for three days, cleavage of the nitrogen-nitrogen bond was achieved. An unusual rearrangement had occurred during the reaction process, compounds 11a,b, containing two carbamate groups on the intercarbonylic position being isolated in moderate yields (Scheme 4, Entries 18 and 22, Table 1). Neither the use of $\mathrm{RuH}_{2}\left(\mathrm{PPh}_{3}\right)_{4}($ Entry 19) nor the presence of isopropanol as hydrogen donor in the reaction mixture (Entries 20, 21 and 23) improved the cleavage process. Experiments performed using only isopropanol as solvent showed longer reaction times. 


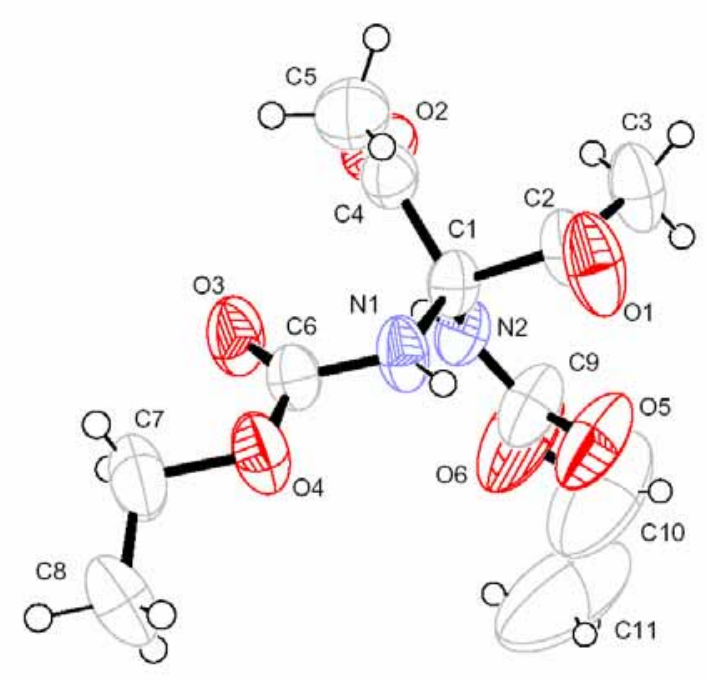

Figure 1. Perspective view of molecule 11a with the crystallographic atom numbering: atoms are represented as their thermal vibration ellipsoids.

Good quality crystals of compound 11a could be obtained and its structure was determined by X-Ray Diffraction (Figure 1). For crystal data and structure refinement see experimental part (Table 2).

Further experiments were carried out with dialkylated $\beta$-dicarbonyl compounds $\mathbf{3}^{10}$ and $12^{21}$ (Schemes 1 and 2 respectively), but no reaction was observed and starting materials were recovered (Entries 24 and 25). So, the presence of the intercarbonylic proton seems to be essential for these cleavages. Likewise the role of the ruthenium catalyst is also essential; starting materials were recovered in a blank experiment. Although the details are not clear, the advantage of using a ruthenium cluster $\left(\mathrm{Ru}_{3}(\mathrm{CO})_{12}\right)$ is the capability for multistep coordination of the substrate. Formation of compounds 11a,b involve cleavage of the $\mathrm{N}-\mathrm{N}$ bond and activation of an alkane C-H bond. Suzuki et al. have previously described that ruthenium polyhydride clusters act as activators of both $\mathrm{N}-\mathrm{N}$ and $\mathrm{C}-\mathrm{H}$ bonds. ${ }^{7 \mathrm{~d}, 22}$ 


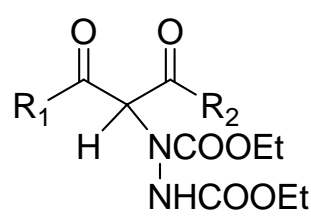

$10 a, b$

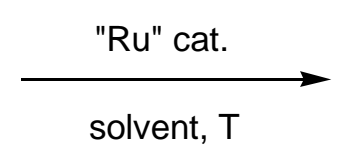

solvent, T

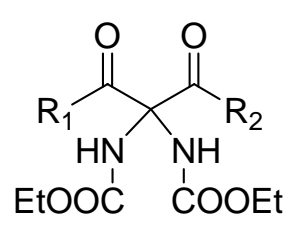

$11 a, b$

a) $\mathrm{R}_{1}=\mathrm{R}_{2}=-\mathrm{CH}_{3}$

b) $\mathrm{R}_{1}=-\mathrm{CH}_{3}, \mathrm{R}_{2}=-\mathrm{OEt}$

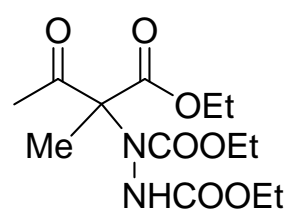

12

Scheme 4. Cleavage of N-N bonds of $N, N$ '-bis(ethoxycarbonyl)hydrazino derivatives catalysed by ruthenium. See experimental conditions in Table 1.

In summary, several experiments have been carried out in order to establish new experimental conditions for the cleavage of nitrogen-nitrogen bonds. The use of $\mathrm{Ru}_{3}(\mathrm{CO})_{12}$ in the presence of isopropyl alcohol as solvent constitutes a new method to break N-N bonds of arylhydrazines, although reaction yields are moderate. No good results were obtained for electron poor aryl hydrazines. Addition of other hydride donor compounds to reaction mixtures, such as sodium hydride or formic acid, did not improve the conversions, but reduce the formation of oxidation products such as azobenzene. Cleavage of the $\mathrm{N}-\mathrm{N}$ bond of trisubstituted electron poor $N, N$ '-bis(ethoxycarbonyl)hydrazino group linked to an intercarbonylic position by a $\mathrm{N}$ atom could also be cleavaged using $\mathrm{Ru}_{3}(\mathrm{CO})_{12}$ but higher temperatures and longer reactions times were required, compared with aryl hydrazines. The presence of isopropanol did not improve the results with these types of compounds.

\section{Experimental Section}

\section{X-ray Crystallographic Study}

A summary of the crystal data and data collection parameters for compound 11a is given in Table 2. A crystal of approximate dimensions of $0.77 \times 0.43 \times 0.25 \mathrm{~mm}^{3}$ was mounted on an EnrafNonius CAD4 diffractometer equipped with a graphite monochromator. Using MoK $\alpha$ radiation and the $\omega-2 \theta$ scan mode, 3704 independent reflections were collected. The structure was solved by direct methods (SHELXS-86) and refined by full-matrix least-squares (SHELXL-93). C-13 atom presents two equally populated disordered positions (only one is shown in the ORTEP 
drawing). Ethoxy groups exhibit large thermal vibration and the terminal C8 and C11 atoms even present disordered positions (only the more occupied sites are shown in the ORTEP drawing). Hydrogen atoms were introduced in calculated positions and refined riding on their parent atoms. Thermal vibration for non $\mathrm{H}$-atoms was assumed to be anisotropic. Crystal packing is dominated by hydrogen bonds along the b axis (N2-H2...O4), d(N2...O4) = 3.124 A).

Table 2. Crystal data and structure refinement for 11a (deposition number at the Cambridge Crystallographic Data Center 616280)

\begin{tabular}{|c|c|c|c|}
\hline Empirical formula & $\mathrm{C}_{11} \mathrm{H}_{19} \mathrm{~N}_{2} \mathrm{O}_{6}$ & $\mathrm{~F}(000)$ & 584 \\
\hline Formula weight & 273.29 & $\begin{array}{l}\text { Standard intensity } \\
\text { decay }\end{array}$ & $0.9 \%$ \\
\hline Temperature & 293(2) K & $\begin{array}{l}\text { PSI scan absorption } \\
\text { correction }\end{array}$ & $\begin{array}{l}\text { Max: } 0.9764, \min = \\
0.8776\end{array}$ \\
\hline Wavelength & $0.71073 \AA$ & $\begin{array}{l}\text { Theta range for data } \\
\text { collection }\end{array}$ & 2.50 to $28.44 \mathrm{deg}$ \\
\hline Crystal system & Monoclinic & Index ranges & $\begin{array}{l}0<=\mathrm{h}<=19 \\
7<=\mathrm{k}<=0 \\
22<=\mathrm{l}<=21\end{array}$ \\
\hline Space group & $\mathrm{P} 2{ }_{1} / \mathrm{C}$ & Reflections collected & 3704 \\
\hline Unit cell dimensions & $\begin{array}{l}a=14.835(3) \AA \\
b=5.870(3) \AA \\
c=16.880(4) \\
\beta=104.86(2)^{\circ}\end{array}$ & $\begin{array}{l}\text { Independent } \\
\text { reflections }\end{array}$ & $\begin{array}{l}3575 \quad[\mathrm{R}(\text { int }) \quad= \\
0.0128)]\end{array}$ \\
\hline Volume & $1420.8(8) \AA^{3}$ & Refinement method & $\begin{array}{l}\text { Full-matrix least- } \\
\text { squares on } \mathrm{F}^{2}\end{array}$ \\
\hline $\mathrm{Z}$ & 4 & Data / parameters & 3575 / 9/ 194 \\
\hline Density (calculated) & $1.278 \mathrm{Mg} / \mathrm{m}^{3}$ & $\begin{array}{l}\text { Goodness-of-fit on } \\
\mathrm{F}^{2}\end{array}$ & 1.144 \\
\hline \multirow[t]{3}{*}{$\begin{array}{l}\text { Absorption } \\
\text { coefficient }\end{array}$} & $0.101 \mathrm{~mm}^{-1}$ & $\begin{array}{l}\text { Final } \quad \mathrm{R} \text { indices } \\
{[\mathrm{I}<2 \sigma(\mathrm{I})]}\end{array}$ & $\begin{array}{l}\mathrm{R} 1=0.0860, \mathrm{wR} 2 \\
=0.2755\end{array}$ \\
\hline & & $\mathrm{R}$ indices (all data) & $\begin{array}{l}\mathrm{R} 1=0.1597, \mathrm{wR} 2= \\
0.3292\end{array}$ \\
\hline & & $\begin{array}{l}\text { Largest diff. Peak } \\
\text { and hole }\end{array}$ & $\begin{array}{l}0.734 \text { and }-0.483 \text { e. } \\
\AA^{-3}\end{array}$ \\
\hline
\end{tabular}

General Procedures. Melting points were determined with a Kofler apparatus and are uncorrected. IR spectra were recorded with an FT-IR spectrophotometer using a single-reflection ATR system as a sampling accessory. NMR spectra were recorded with a Brucker-Analytik 
AC250. ${ }^{1} \mathrm{H}$ NMR $\left(250 \mathrm{MHz}\right.$ ) chemical shifts are reported relative to $\mathrm{CHCl}_{3}$ at $\delta=7.28$ and tetramethylsilane at $\delta=0.00 .{ }^{13} \mathrm{C} \mathrm{NMR}(62.5 \mathrm{MHz})$ are reported relative to $\mathrm{CHCl}_{3}$ at $\delta=77.0$ and tetramethylsilane at $\delta=0.0$. MS spectra were recorded on a Hewlett-Packard 5989 A and determined at an ionizing voltage of $70 \mathrm{eV}$ or chemical ionization with $\mathrm{NH}_{3}$ molecules; relevant data are listed as $\mathrm{m} / \mathrm{z}$ (\%). Mass spectra were determined at "Servei d'Anàlisi Química de la Universitat Autònoma de Barcelona”. $\mathrm{Ru}_{3}(\mathrm{CO})_{12}$ and $\left[\mathrm{Ru}(\mathrm{AcO})(\mathrm{CO})_{2}\right]_{\mathrm{x}}$ are commercially available, and $\mathrm{RuH}_{2}\left(\mathrm{PPh}_{3}\right)_{4}$ was prepared following a described method. ${ }^{9}$ Compounds 6a-f are commercially available as hydrazines or their corresponding chlorhydrates. Compounds $\mathbf{3},{ }^{10}$ $\mathbf{1 0 a}{ }^{20} \mathbf{1 0 b}^{20}$ and $\mathbf{1 2}^{21}$ have been synthesized as previously described in the literature. Compounds $\mathbf{7 a - b},{ }^{23} \mathbf{7} \mathbf{c},{ }^{24} \mathbf{7 d},{ }^{25} \mathbf{9} \mathbf{e}^{26}$ and $\mathbf{1 1} \mathbf{b}^{27}$ as well as the diacetylated compounds ${ }^{28}$ mentioned in Table 1 have been previously characterized. All procedures were carried out under inert atmosphere using anhydrous standard purified solvents. Standard flash chromatography procedures were followed using 230-400 mesh silica gel.

Reaction of $\mathrm{Ru}_{3}(\mathrm{CO})_{12}$ with 1,2-diphenylhydrazine 6a (Entry 1). 1,2-Diphenylhydrazine 6a (0.20 g, $1.08 \mathrm{mmol})$ and $\mathrm{Ru}_{3}(\mathrm{CO})_{12}(0.047 \mathrm{~g}, 0.07 \mathrm{mmol}, 6 \% \mathrm{M})$ were disolved in anhydrous acetonitrile $(0.37 \mathrm{~mL})$. The mixture was refluxed for 24 hours, then acetic anhydride $(0.35 \mathrm{~mL}$, $3.72 \mathrm{mmol}$ ) was added, and the solution was heated for 4 hours more at $80^{\circ} \mathrm{C}$. Then solvent was evaporated, and the black oily residue was chromatographed through silica gel using AcOEt/Hexanes of increasing polarity as eluent. $N$-phenylacetamide $7 \mathbf{a}(0.11 \mathrm{~g}, 35 \%$ yield $)$ and azobenzene $8 \mathbf{a}$ ( $0.10 \mathrm{~g}$, 50\% yield) were isolated.

Reaction of $\mathbf{R u}_{3}(\mathbf{C O})_{12}$ with 1,2-diphenylhydrazine (Entry 7). Sodium hydride (0.03 g, 1.30 mmol) were introduced in isopropanol $(1.6 \mathrm{~mL})$, then $\mathbf{6 a}(0.49 \mathrm{~g}, 2.66 \mathrm{mmol})$ and $\mathrm{Ru}_{3}(\mathrm{CO})_{12}$ $(0.11 \mathrm{~g}, 0.17 \mathrm{mmol})$ were added and the mixture was refluxed for 18 hours. The solvent was destillated and acetic anhydride $(0.90 \mathrm{~mL}, 9.57 \mathrm{mmol})$ was added to the residue, and then the mixture was refluxed for 4 hours. After evaporation of the mixture, the residue was chromatographed through silica gel using AcOEt/Hexanes of increasing polarity as eluent. $N$ phenylacetamide $7 \mathbf{a}(0.22 \mathrm{~g}, 31 \%$ yield $)$ and azobenzene $8 \mathrm{a}$ ( $0.09 \mathrm{~g}$, 19\% yield) were isolated.

Reaction of $\mathrm{Ru}_{3}(\mathrm{CO})_{12}$ with 3-[N,N'-bis(ethoxycarbonyl)hydrazino]pentane-2,4-dione 10a (Entry 21). 10a (1.00 g, $3.65 \mathrm{mmol})$ and of $\mathrm{Ru}_{3}(\mathrm{CO})_{12}(0.14 \mathrm{~g}, 0.22 \mathrm{mmol}, 6 \% \mathrm{M})$ were dissolved in a mixture of anhydrous isopropanol $(0.84 \mathrm{~mL}, 10.97 \mathrm{mmol})$ and anhydrous acetonitrile $(1.50 \mathrm{~mL})$, then the solution was heated at $120^{\circ} \mathrm{C}$ in a closed reactor for 72 hours. After evaporation of the solvents, the residue was chromatographed through silica gel using AcOEt/Hexanes of increasing polarity as eluent affording 11a (0.24 g, 24\% yield). Mp: 126-127 ${ }^{\circ} \mathrm{C}$. IR (ATR): 3406, 3361, 2991, 2985, 2965, 1720, 1489, $1252 \mathrm{~cm}^{-1} .{ }^{1} \mathrm{H}-\mathrm{NMR} \delta$ (ppm): 1.27 (t, $J=7.2 \mathrm{~Hz}, 6 \mathrm{H}$ ), 2.14 (s, 6H), 4.14 (q, $J=7.2 \mathrm{~Hz}, 4 \mathrm{H}$ ), 6.92 (broad band, 2H, NH). ${ }^{13} \mathrm{C}-\mathrm{NMR} \delta$ (ppm): 14.3, 22.9, 61.6, 80.8, 154.7, 197.0. EIMS (m/z): $292\left(\mathrm{M}+\mathrm{NH}_{4}\right)^{+}, 275(\mathrm{M}+1)^{+} . \mathrm{X}$-ray diffraction confirmed the structure. 


\section{Acknowledgements}

We acknowledge financial support from "Ministerio de Educación y Ciencia” of Spain (Projects BQU2002-04002 and CTQ-2005-04968/BQU) and “Generalitat de Catalunya” (Projects 2001SGR00181, 2005SGR-452 and 2005SGR00305). One of us (R.M.S.) has been incorporated into the research group through a "Ramon y Cajal" contract (MCYT-FEDER/FSE). The "Ministerio de Educación y Ciencia" is also gratefully acknowledged for predoctoral scholarships to S.M and E.T.

\section{References and Notes}

1. Gilchrist, T. L. In Comprehensive Organic Synthesis, Trost, B. M.; Fleming I., Eds.; Pergamon: Oxford, 1991; Vol. 8, pp 388-389.

2. (a) Stetter, H.; Spangenberger, H. Chem. Ber. 1958, 91, 1982. (b) Nelsen, S. F.; Willi, M. R. J. Org. Chem. 1984, 49, 1. (c) Alexakis, A.; Lensen, N.; Mangeney, P. Tetrahedron Lett. 1991, 32, 1171. (d) Alexakis, A.; Lensen, N.; Mangeney, P. Synlett 1991, 625.

3. (a) Lunn, G.; Sansone, E. B.; Keefer, L. K.; Keefer, L. K. Synthesis, 1985, 12, 1104. (b) Alonso, F.; Radivoy, G.; Yus, M. Tetrahedron 2000, 56, 8673. (c) Alonso, F.; Candela, P.; Gómez, C.; Yus, M. Advanced Synthesis and Catalysis 2003, 345, 275.

4. (a) Kemp, D. S.; Sidell, M. D.; Shortridge, T. J. J. Org. Chem. 1979, 44, 4473. (b) Mellor, J. M.; Smith, N. M. J. Chem. Soc. Perkin Trans 1 1984, 2927. (c) Denmark, S. E.; Nicaise, O.; Edwards, J. P. J. Org. Chem. 1990, 55, 6219.

5. (a) Feuer, H.; Brown, F. J. Org. Chem. 1970, 35, 1468. (b) Enders, O.; Lochtam, R.; Meiers, M.; Müller, S.; Lazny, R. Synlett 1998, 1182.

6. (a) Souppe, J.; Danon, L.; Namy, J. L.; Kagan, H. B. J. Organomet. Chem. 1983, 250, 227.

(b) Burk, M. J.; Martínez, J. P.; Feaster, J. E.; Cosfrod, N. Tetrahedron 1994, 50, 4399. (c) Kobayashi, S.; Hirabayashi, R. J. Am. Chem. Soc. 1999, 121, 6942. (d) Ding, H.; Friestad, G. K. Org. Lett. 2004, 6, 637.

7. (a) Schrock, R. R.; Glassman, T. E.; Vale, M. G. J. Am. Chem. Soc. 1991, 113, 725. (b) Nakajima, Y.; Suzuki, H. Organometallics 2003, 22, 959. (c) Seino, H.; Masumori, T.; Hidai, M.; Mizobe, Y. Organometallics 2003, 22, 3424. (d) Nikajima, Y.; Inagaki, A.; Suzuki, H. Organometallics 2004, 23, 4040. (e) Takei, I.; Dohki, K.; Kobayashi, K.; Suzuki, T.; Hidai, M. Inorg. Chem. 2005, 44, 3768.

8. Hallmann, P. S.; Stephenson, T. A.; Wiklinson, G. Inorg. Synth. 1970, 12, 238.

9. Young, R.; Wilkinson, G. Inorg. Synth. 1990, 28, 337.

10. Lumbierres, M; Marchi, C; Moreno-Mañas, M.; Sebastián, R. M.; Vallribera, A.; Lago, E.; Molins, E. Eur. J. Org. Chem. 2001, 2321.

11. Gimbert, C.; Lumbierres, M.; Marchi, C.; Moreno-Mañas, M.; Sebastián, R. M.; Vallribera, A. Tetrahedron 2005, 61, 8598. 
12. (a) Alonso, D. A.; Brandt, P.; Nordin, S. J. M.; Andersson, P. G. J. Am. Chem. Soc. 1999, 121, 9580. (b) Naota, T.; Takaya, H.; Mirahashi, S.I. Chem. Rev. 1998, 98, 2599.

13. Toti, A.; Frediani, P.; Salvini, A.; Rosi, L.; Giolli, C. J. Organomet. Chem. 2005, 690, 3641.

14. (a) Basu, A.; Bhaduri, S.; Sharma, K.; Jones, P. G. J. Chem. Soc., Chem. Commun. 1987, 1126. (b)Yamakawa, M.; Ito, H.; Noyori, R. J. Am. Chem. Soc. 2000, 122, 1466. (c) Laxmi, Y. R. S.; Backvall, J. E. Chem. Commun. 2000, 7, 611.

15. Chandrasekhar, S.; Reddy, Ch. R.; Rao, R. J. Synlett 2001, 10, 1561.

16. Uematsu, N.; Fujii, A.; Hashiguchi, S.; Ikariya, T.; Noyori, R. J. Am. Chem. Soc. 1996, 118, 4916.

17. (a) Meseguer, M.; Moreno-Mañas M.; Vallribera, A. Tetrahedron Lett. 2000, 41, 4093. (b) Marchi, C.; Trepat, E.; Moreno-Mañas, M.; Vallribera, A.; Molins, E. Tetrahedron, 2002, 58, 5699. (c) Comelles, J.; Moreno-Mañas, M.; Pérez, E.; Roglans, A.; Sebastián, R. M.; Vallribera, A. J. Org. Chem. 2004, 69, 6834.

18. For a review on metal catalyzed Michael Additions see: Comelles, J.; Moreno-Mañas, M.; Vallribera, A. Arkivoc 2005, 9, 207.

19. (a) Evans, D. A.; Britton, T. C.; Dorow, R. L.; Dellaria, J. F. J. Am. Chem. Soc. 1986, 108, 6395 (b) Evans, D. A.; Britton, T. C.; Dellaria, J. F. Tetrahedron 1988, 44, 5525. (c) Harris, J. M.; Bolessa, E. A.; Mendonca, A. J.; Feng, S. C.; Vederas, J. C. J. Chem. Soc. Perkin Trans 1 1995, 1945. (d) Demberch, P.; Seconi, G.; Ricci, A. Chem. Eur. J. 2000, 6, 1281.

20. Nelson, J. H.; Howels, P. N.; Lauten, G. L.; DeLullo, G. C.; Landen, G. L. J. Org. Chem. 1980, 45, 1246.

21. Clariana, J; Gálvez, N.; Marchi, C.; Moreno-Mañas, M.; Vallribera, A.; Molins, E. Tetrahedron 1999, 55, 7331.

22. Suzuki, H. Eur. J. Inor. Chem. 2002, 1009.

23. Kubota, T.; Miyashita, S.; Kitazume, T.; Ishikawa, N. J. Org. Chem. 1980, 45, 5052.

24. Sanford, J. K.; Blair F. T.; Arroya, J.; Sherk K. W. J. Am. Chem. Soc. 1945, 1941.

25. Lobo, A. M.; Marques, M. M.; Prabhakar S.; Rzepa, H. S. J. Org. Chem. 1987, 52, 2925.

26. Makosza, M.; Bialecki, M. J.Org. Chem. 1998, 63, 4878

27. Felice, E.; Fioravanti, S.; Pellacani, L.; Tardella, P. A. Tetrahedron Lett. 1999, 40, 4413.

28. Meyer, H. J.; Nolde, C.; Thomsen, I.; Lawesson, S. O. Bull. Soc. Chim. Belg. 1978, 87, 621. 